\title{
The Interface of Orality and Writing
}

\author{
Speaking, Seeing, Writing in the Shaping of New Genres \\ Ed. by Annette Weissenrieder and Robert B. Coote
}

[Die Verbindung von Mündlichkeit und Schriftlichkeit. Hören, Sehen und Schreiben als neue Gattungen.]

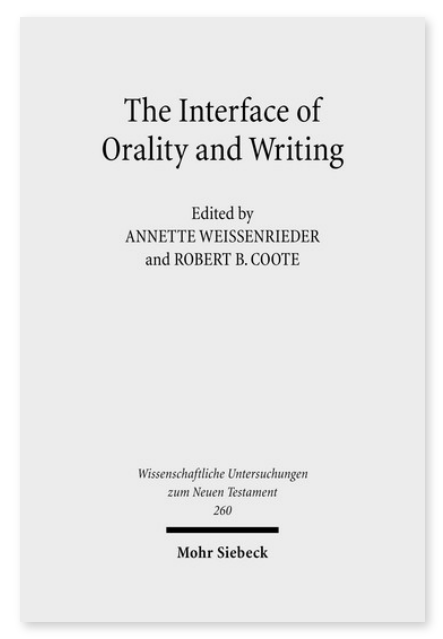

2010. XIV, 438 Seiten. WUNT I 260

ISBN 978-3-16-151549-1

DOI 10.1628/978-3-16-151549-1

eBook PDF $149,00 €$

ISBN 978-3-16-150445-7

Leinen $149,00 €$
Veröffentlicht auf Englisch.

In welcher Weise waren in der Antike das Visuelle, das Mündliche und das Geschriebene miteinander verknüpft? Die Autoren der vorliegenden Studien untersuchen die miteinander konkurrierenden und sich ergänzenden Rollen der visuellen Medien, Gedächtnisformen, der Lesefähigkeit und Volkskultur in der antiken mediterranen Welt. Durch die Einbeziehung herkömmlicher und innovativer Perspektiven, nähern sie dich Studien den Grenzen im Verständnis um die Art der Texte bezüglich ...

Inhaltsübersicht

I. Introduction The Interface of the Orality and Writing Hearing, Seeing, Writing in New Genres

Susan Niditch: Hebrew Bible and Oral Literature: Misconceptions and New Directions - Teun Tieleman: Orality and Writing in Ancient Philosophy: Their Interrelationship and the Shaping of Literary Forms - Catherine Hezser: From Oral Conversations to Written Texts: Randomness in the Transmission of Rabbinic Traditions - Antoinette Clark Wire: Mark: News as Tradition Werner Kelber: The History of the Closure of Biblical Texts

II The Interface of the Orality and Writing Hearing in New Genres

John Foley: Plenitude and Diversity: Interactions between Orality and Writing - Kristina Dronsch: Transmissions from Scripturality to Orality: Hearing the Voice of Jesus in Mark 4:1-34 - Ruben Zimmermann: Memory and Form Criticism: The Typicality of Memory as a Bridge between Orality and Literality in the Early Christian Remembering Process - Richard Horsley: The Gospel of Mark in the Interface of Orality and Writing - David Rhoads: Performance Events in Early Christianity: New Testament Writings in an Oral Context - David Trobisch: Performance Criticism as an Exegetical Method: A Story, Three Insights, and Two Jokes

III. The Interface of the Orality and Writing Seeing in New Genres

Kristina Dronsch/Annette Weissenrieder: A Theory of the Message for New Testament Writings or Communicating the Words of Jesus: From Angelos to Euangelion - David Balch: Women Prophets/Maenads Visually Represented in Two Roman Colonies: Pompeii and Corinth - Annette Weissenrieder: The Didactics of Images: The Fig-Tree in Mark 11:12-14 and 20-21

IV. The Interface of the Orality and Writing Writing in New Genres Annette Schellenberg: A »lying pen of the scribes« (Jer 8:8)? Orality and Writing in the Formation of Prophetic Books - Roger Nam: Writing Songs, Singing Songs: The Oral and the Written in the Commission of the Levitical Singers (1 Chr 25:1-6) Andreas Schuele: "Call on me in the day of trouble [...]« From Oral Lament to Lament Psalms - Pieter J.J. Botha: »Publishing« a Gospel: Notes on Historical Constraints to Gospel Criticism - Danie/ Boyarin: The Sovereignty of the Son of Man: Reading Mark - Robert Coote: Scripture and the Writer of Mark - Holly Hearon: Mapping Written and Spoken Word in the Gospel of Mark - Trevor Thompson: Writing in Character: Claudius Lysias to Felix as a Double-Pseudepigraphon (Acts 23:26-30)

Robert B. Coote is Nathaniel Gray Professor of Hebrew Exegesis and Old Testament, San Francisco Theological Seminary and the Graduate Theological Union.

Annette Weissenrieder Born 1967; Professor of Exegesis and Theology of New Testament at the Faculty of Theology at the Martin-Luther-University and director of the Institute »Corpus Hellenisticum«, University of Halle-Wittenberg.

Jetzt bestellen:

https://mohrsiebeck.com/buch/the-interface-of-orality-and-writing-9783161515491?no_cache=1

order@mohrsiebeck.com

Telefon: +49 (0)7071-923-17

Telefax: +49 (0)7071-51104 